\title{
State-local Coordination in Managing Land Use and Transportation Along State Highways by
}

\author{
Salila Vanka ${ }^{1}$; Susan Handy (Corresponding author) ${ }^{2}$; Kara M. Kockelman ${ }^{3}$ \\ The following paper is a pre-print and the final publication can be found in \\ Journal of Urban Planning and Development 131 (1): 10-18, 2005.
}

\begin{abstract}
The access that state highways provide to adjacent land enables the development of that land. Although access alone does not ensure that development will occur, land with access from a state highway has considerably greater development potential than land without such access. City governments regulate the development of the land, while the state Departments of Transportation (DOTs) wield authority over the adjacent state highways. This separation of authority creates a significant challenge for state DOTs as they work to expand state highway facilities in a bid to stay apace with the explosive growth of U.S. metropolitan areas. This paper identifies methods adopted by local governments and state DOTs to coordinate land use policies and manage development along state highways. We find that regardless of whether a state has legislation that supports state-local cooperation, the city government's willingness to partner with the DOT remains a critical factor in the success of coordination efforts for managing land use along state highways.
\end{abstract}

CE Database Keywords: Inter-agency coordination; Planning; Land use; State highway; Department of Transportation; Local government

\section{Introduction}

In their traditional roles, city governments and state Departments of Transportation (DOTs) have authority over two distinct areas of planning. City governments are enabled by state law to shape local land use decisions, while the authority of transportation agencies ends at the right-of-way (ROW) boundaries of the state highways that link many of these land uses. The challenges posed by this separation of authority are often compounded by conflicting goals: while the state DOT strives to maintain acceptable levels of service (LOS) on existing highways and plan for future highway expansions, city governments are often eager to allow (or unwilling or unable to stop) development along the highway that generates local traffic and may restrict future expansions. In areas of the U.S. experiencing rapid growth, the problem is especially acute.

\footnotetext{
${ }^{1}$ M.S. Community and Regional Planning, The University of Texas at Austin, 1 University Station B7500, Austin, TX 787120222. Phone: (512) 494 8381. Email: salilas@mail.utexas.edu

${ }^{2}$ Associate Professor of Environmental Science and Policy, The University of California at Davis, One Shields Avenue, Davis, CA 95616-8573. Phone: (530) 752-5878, Fax: (530) 752-3350. Email: slhandy@ ucdavis.edu

${ }^{3}$ Clare Boothe Luce Professor of Civil Engineering, The University of Texas at Austin, 1 University Station C1761, Austin, TX

78712. Phone: (512) 471 0210, Fax: (512) 475 8744. Email: kkockelm@ mail.utexas.edu
} 
This paper explores efforts by city governments and state DOTs across the United States to achieve to overcome the challenges posed by separation of authority and differences in goals through inter-agency cooperation and coordination. We conducted in-depth interviews with 52 state and local officials from 11 states to identify alternative approaches to coordination, uncover best practices, and draw lessons from the experiences of those interviewed. The results provide a catalogue of ideas and important insights for other communities seeking to improve state-local coordination in the management of transportation and land use along state highways.

\section{Background}

A growing recognition of the effect of land use decisions on transportation facilities - and the reverse - has contributed to the development of new planning practices in state and local agencies in the U.S., including corridor preservation and access management (Lazarz 1994). Efforts to preserve ROW along state facilities go back 30 to 40 years (Bass et al. 1996), though the Intermodal Surface Transportation Efficiency Act (ISTEA) of 1991 created a new impetus for states to identify corridors for preservation for new highways and highway expansions in their transportation plans (Secretary of Transportation 1994). Access management efforts, which aim to balance land development with the preservation of traffic flow on existing facilities (Victoria Transport Policy Institute 2002), have also increased, particularly where highway expansion would be costly or infeasible.

Existing research suggests that comprehensive planning for transportation corridors can be achieved either by empowering local governments by state legislation to cooperate in land use planning or by creating regional agencies that have authority to do land use and transportation planning at a regional level (Carlson and King 1998). In states that have laws enabling interjurisdictional cooperation, Carlson and King (1998) identified certain key factors that allow local governments to successfully apply these laws: (1) financial incentives from state and regional governments to encourage local government cooperation; (2) support of inter-agency collaboration by state officials; and (3) public recognition that the state has land use and transportation problems that require inter-jurisdictional solutions (Carlson and King 1998). Few communities, however, have all of these factors in place.

In the absence of state legislation, efforts to coordinate land use and transportation along state highways depend on the cooperation of state DOTs and local agencies and range from informal inter-agency cooperation to formal inter-agency agreements. In a study of corridor management practices across the country, a National Cooperative Highway Research Program (NCHRP) synthesis report identified inter-agency coordination and public involvement as integral to all aspects of corridor management (NCHRP 2000). Another NCHRP report concluded that effective intergovernmental relationships "exhibit both horizontal (interjurisdictional) and vertical (intergovernmental) relationships; deal explicitly with politics (the degree to which agencies are willing to sacrifice their autonomy will shape the nature of the relationships that develop); encompass a variety of mechanisms, from formal agreements to loose cooperative affiliations; and build on interdependence among agencies” (NCHRP 2001, p.11). However, building effective relationships between local, state, and regional entities is often hindered by the complexity of achieving intergovernmental cooperation between "multiple jurisdictions, each with independent resources, different laws and policies and generally distinct planning objectives” (NCHRP 2001, p.10). The experiences of state DOTs that have built 
effective relationships with local agencies offer important lessons for overcoming these challenges.

\section{Practices and Problems in State-Local Coordination of Land Use and Transportation Decisions}

This paper is based on research we conducted for Texas DOT (TxDOT) between June-August 2002 (Vanka, et al. 2002). The findings are derived from in-depth, open-ended interviews by phone or in person with 52 officials from state DOTs, local jurisdictions, and consulting firms in eleven states in the U.S. (Colorado, Delaware, Florida, Kansas, Maryland, Michigan, New Jersey, Oregon, Texas, Washington, Wisconsin). These interviews were conducted between July 3 and August 15, 2002. The respondents were selected from: (1) attendees of the Fifth Access Management Conference of the Transportation Research Board (held in Austin in June 2002), (2) officials recommended by the first set of respondents, and (3) an extensive literature review. The respondents are listed in Table 1.

Table 1 goes here

It is important to note that this research was exploratory in nature, in that the goal was to identify the full range of approaches used to coordinate land use and transportation along state highways and to examine qualitatively the experiences of those officials involved in coordination efforts; the study was not designed to quantitatively assess the pervasiveness of different approaches or their effectiveness. Respondents were asked to comment on the following topics:

- Conflicts over land use along state highways

- State and city actions that enable coordination

- Effectiveness of regulations on coordination efforts

- Other forums for interaction and coordination

- Best practices

\section{Conflicts over Land use along State Highways}

The concerns voiced by the respondents about managing land use adjacent to state highways relate to provision and control of access particularly for commercial development. DOT officials from all eleven states highlighted the difficulty of maintaining capacity and safety as land development continues unabated along the state facility. Conflicts often arise between a city and DOT in planning for fast-developing rural or suburban areas in close proximity to a highway facility. Similar problems also commonly occur outside the city limits and in unincorporated areas that have inadequate infrastructure. Higher levels of land development could require corresponding changes in the categories of the state highway, which would then change the parameters of access accordingly. Some local agencies are reluctant to preserve land in a currently developing area to accommodate a future interchange and the DOT cannot require them to preserve or dedicate ROW. DOT participation in local land use planning is also limited as the city agencies are not obligated to discuss land development proposals for properties not abutting the state highway with the DOT, irrespective of their impacts on the highway. In some cases, developers may take advantage of loosely defined zoning categories to overbuild on a plat, thereby generating unanticipated traffic levels. Similarly, incremental parcel planning by the local authorities along the highway can cause a frontage road to function as a minor arterial 
without the capacity to handle the traffic. In general, the DOT is reluctant to compromise level of service on a facility, while the city has to struggle with the demands of new land development.

\section{State and City Actions that Enable Coordination}

Limited resources, conflicting priorities and weak regulations characterize the present-day scenario within which local agencies and state DOTs have to perform their functions. Local politics, bureaucracy, and inadequate communication also hinder interaction between the DOT and city officials. However, the respondents identified some opportunities for state DOTs and local officials to work together within such constraints.

State DOTs and local governments can work together in the review of land development applications for properties abutting highways because the builder requires a building permit from the city and an access permit from the DOT district office. In access permit reviews, the district DOT offices review and analyze trip generation and operational challenges related to the development proposal, but they do not analyze the land development itself. In nine out of the eleven states, officials from city and district DOT offices communicate regularly by sharing information through phone calls, emails and meetings. District officials from Colorado DOT (CDOT) involve the county/city during a highway access permit process in pre-application meetings. City of Portland officials conduct pre-application conferences for major zoning changes and applications that are attended by affected city agencies, state agencies and permit applicants. In Florida, city and Florida DOT (FDOT) staff work to improve inter-agency coordination by sharing information on an informal basis, attending development site plan meetings, participating in site plan reviews, and staying updated on current issues (Marshall and Williams 1998). Some Florida counties require FDOT involvement in any land development review as part of their land development codes.

DOT officials also lend their expertise to city agencies in assessing land use impacts on traffic. District offices in Florida provide technical assistance and training to city officials in determining how much capacity a certain roadway can handle, and hence the amount of land development the city can approve on that roadway. Washington DOT (WSDOT) officials work with communities in creating "route development plans" for highways in their region. In 1998, Wisconsin DOT (WisDOT) initiated the process of working with (and in some cases, funding) municipalities on certain highway corridors to create corridor plans. These corridor plans address land development issues and propose improvements not only to the state highway but also to adjacent local roads.

In five states, DOT staff is invited to comment on the transportation element of the city's comprehensive plan or zoning plans. However, the DOT generally has no authority to weigh in and identify land use conflicts vis-à-vis the state highway. Usually cities and DOTs work together in determining the access points along a state highway within city limits. City officials tend to defer these decisions to the DOT because 1) they acknowledge the DOT engineers' experience and expertise in traffic operations and 2) they want to avoid liability for any safety or operational problems that may arise from such decisions.

Respondents from five states emphasized the need to involve the development community in the coordination process. TxDOT officials in San Antonio find that engaging city 
officials, developers, and engineers in discussions during the early stages of a proposed land development project benefits all parties concerned. ODOT holds conferences with city officials and local developers to discuss mutual concerns. WSDOT provides information and assistance to the developer community across the state through its "Developer Agreement Guidebook" and "Highway Access Management Guidebook”.

In eight states included in this study, DOTs take the help of other state/regional agencies to provide assistance to communities in planning for access control. Michigan DOT enlists the help of State Regional Planning Agencies while working with local jurisdictions on access issues. Oregon State's Department of Land Conservation and Development has a program that provides assistance to developers with problematic site proposals in modifying their proposal such that it meets the developer's plans and Oregon DOT's (ODOT) requirements. Meetings with the MPO provide another forum for DOT and city officials to discuss issues at a more regional level. Though it always functions in an advisory capacity in such matters, the MPO is seen to play a more important role in fostering coordination in some states than others.

The level of interaction and coordination between city and DOT officials varies from one city to another, and this is typically a function of the relations between the state and local officials. The interviews also suggest that cities recognizing the connection between continued prosperity in their retail sector and unclogged highway systems are more likely to coordinate with DOTs on planning for land use and road networks.

\section{Effectiveness of Regulations on Coordination Efforts}

Nine states in this study have some form of state legislation that directly or indirectly encourages state-local collaboration in managing land use and transportation planning. Of these, five states have legislation giving the DOT direct authority to control access to the highways while in the other states, growth management laws have facilitated interaction between state and local agencies. Table 2 lists state-mandated policies and legislations that directly or indirectly encourage state-local coordination in managing land use and transportation.

Table 2 goes here

DOT officials in five states opined that state-mandated access rules played a crucial role in enabling their working together with city governments. Delaware DOT (DelDOT) relies on state-approved corridor preservation legislation to contain highway expansion and get communities’ buy-in. Kansas DOT (KDOT) works with cities through inter-governmental agreements and a voluntary corridor management program. In cities willing to participate in corridor preservation, KDOT has the authority to review all the development projects occurring within the corridor plan area. Both city and KDOT officials have positive comments about the program and emphasize that funding incentives from the state are crucial for attracting city participation. The City of Hays, Kansas now uses the principles and philosophy of access control in evaluating their local street network and platting even in areas not under the jurisdiction of their corridor management plan.

DOT officials from Maryland and Wisconsin said that introducing Smart Growth legislation opened up new possibilities for generating creative solutions. Maryland's Smart 
Growth and Neighborhood Conservation Act provided Maryland DOT a thrust towards getting involved in projects traditionally outside their mandate. Similarly, Wisconsin’s Smart Growth legislation creates a new channel for communication between the city and MPO by requiring cities to coordinate the transportation component of their comprehensive plans with the local MPO.

State-mandated regulations and policies play a significant role in defining the DOT's approach to highway planning and in educating communities about issues concerning land use and the highway system. While these regulations set the tone for the state's approach to land use and transportation planning, the respondents' answers indicate that the successful

implementation of these regulations still largely depends on the local jurisdiction's willingness to cooperate with the state agency.

\section{Other Forums for Interaction and Coordination}

Respondents from all eleven states identified project-by-project meetings and MPO meetings as the most common forums for interaction with each other. Beside these, city and DOT officials from six of the eleven states talked about other opportunities that they have to meet and discuss transportation and land use planning issues. These opportunities occurred at either the local or regional level.

In six states, district DOT officials hold regular meetings with city officials where they discuss any topic related to land use and transportation. In Colorado, Delaware and Michigan, DOT officials create opportunities for communities to learn about access management issues by arranging classes, seminars and workshops. The City of Madison, Wisconsin appoints DOT staff to some of its local boards and commissions. Therefore WisDOT staff is aware of all major development proposals that come into the city.

In Maryland, officials at the state headquarters work constantly with the county planning departments on broader policy issues. Maryland has an annual program since the 1950s under which Maryland DOT staff goes to each county and talks with the local elected officials about their plans for the next year. New Jersey DOT (NJDOT) and the Central New Jersey MPO participate along with New Jersey Transit, and all counties and local governments in the Central Jersey Area in the Central Jersey Transportation Forum that examines land use and transportation issues from a regional perspective.

In 1991, Washington State created Regional Transportation Planning Organizations (RTPOs) that perform the role of MPOs in rural areas. The RTPO could be a county, regional council, city, town or WSDOT region office and assists in the development and coordination of the regional transportation plan. By state law, RTPOs are required to certify that the local jurisdiction's comprehensive plan transportation element is consistent with the regional plan, and provide another forum for WSDOT to interact with local agencies.

The respondents welcomed more opportunities to meet with officials from the other agencies because this helped them share information and build good working relations with each other. Most respondents stated that developing close ties with their colleagues from other 
agencies in turn fostered better communication and understanding between them and improved the entire coordination process in the long term.

\section{Best Practices}

Based on their experiences, the respondents provided some interesting and instructive examples of successful coordination efforts in their states. It is interesting to note that in nearly all the examples of best practices, the process was successful because the local jurisdiction displayed a willingness to cooperate with the DOT.

Land use and zoning controls in Lakeland, Florida. As a regional center located between Tampa and Orlando, the city of Lakeland, Florida has extensive commercial activity along its busy state highways. Five years back, in an effort to regulate aesthetics and land use at state highway interchanges, Lakeland officials adopted a new land use category called "interchange activity center". This special land use category limits the types of land uses and encourages consolidation of access points located around highway interchanges. The city also uses zoning tools like planned unit developments and encourages nodal development to manage land use and transportation, especially in locations facing traffic capacity or operational problems. City officials are currently working with FDOT to create a Corridor Access Management Plan (CAMP) for US-98 in Lakeland. This CAMP is also integrated into the city's comprehensive plan.

Access Controls in Zoning Ordinance - Delta Township, Michigan. State highway M-43 passes through Delta Township, located to the west of Lansing, Michigan. Also known as the Trunkline, M-43 is a 100 feet wide 5-lane highway with commercial strip development abutting it. Concerns for traffic safety, conflicts with MDOT policies and burgeoning commercial development motivated the township to adopt standards controlling access along the Trunkline. Delta Township adopted a new zoning ordinance called "The Delta Charter Township Zoning Ordinance of 1990" that included a section imposing access control standards on land uses along M-43. The standards were reviewed and approved by MDOT before being incorporated into the Township’s zoning ordinance. Among other benefits, the access control standards helped Township officials to tie parking lots together so that residents could move between the commercial developments using internal streets instead of the Trunkline.

State-local coordination in San Antonio, Texas. When a developer approaches the City of San Antonio with a design proposal for property along a state highway, the City involves the local TxDOT office in the review process. TxDOT officials review the design and send their comments to the city within two weeks. City officials forward these comments to the developer who makes the necessary changes required to get his building permit. For the past two years, city officials have also been sending traffic impact analyses for all properties on or off TxDOT ROW to the TxDOT office for review and comment. In the absence of formal agreements, this voluntary coordination process evolved between city and state officials from mutual respect and knowledge that by working together they can optimize limited resources and achieve better planning results.

Snohomish County-Washington State Interlocal Agreement. Washington State's GMA and SEPA rules encourage state-local coordination in land use-transportation planning but they do 
not specify actions enabling such coordination. Local jurisdictions decide if they want to work with the DOT on issues such as site plan reviews and developer charges. In 1998, Snohomish County made an interlocal agreement with WSDOT, according to which all development proposals in the county would be sent to the DOT for review, and WSDOT could collect a flat fee for developments abutting state highways. Local developers were involved in entire process of forging the agreement. Four years later, the agreement remains a success. The factors contributing to the agreement's success were: local officials who understood the benefits of transportation-land use coordination; a good working relationship between WSDOT and county staff; local political awareness and support; and a Planning Board willing to adopt a new approach. Contrary to expectations, developers had no complaints about the fees since they knew what they were expected to pay upfront, without any future surprises.

Reservation Policy on US 301, Maryland. The US 301 project in Maryland was an effort to manage traffic and growth along that corridor. Officials from MDOT and local jurisdictions worked together to prepare a corridor preservation plan for this 50-mile corridor. Prince George's County adopted a “reservation policy” to preserve land for future ROW needs. As per this policy, if MDOT officials identified a certain property because it affects the highway ROW, they could approach the county about putting that property in reservation. This dialogue happens through the Maryland National Capital Park and Planning Commission, a bi-county agency serving Prince George's and Montgomery counties. The Commission makes an agreement with the property owners that they will not sell or develop that property for the next 3 years. The property owners do not have to pay any taxes for their land while it is in reservation. After the three years end, if the state wants to put the property back in reservation, the property owners have to be approached again.

Access Management in Oshtemo Township, Michigan. Oshtemo Township, one of the main growth areas in Kalamazoo County, Michigan adopted an access management (AM) program in 1986. The Township was confronted with the challenge of managing commercial land use and access along State Highway M-43. The concept of AM was introduced in Oshtemo by its Planning Director. According to Oshtemo’s AM ordinance, every building proposal (except single family homes) submitted for development review process was subject to AM standards. The standards addressed issues from the number and location of driveways to creating opportunities for service roads, sharing drives and cross parking arrangements. After resistance for the first 2-3 years, local developers accepted the standards like they would any set of design guidelines. The local MPO, Michigan DOT and County Road Commission worked with Township planning staff by providing them with technical support and participating in Board meetings. The Oshtemo experience was made possible by a combination of interagency cooperation and effective local AM regulations.

Growth Management on Perryman Peninsula, Maryland. State-local coordination in the Perryman Peninsula area of Harford County, Maryland was helped by the state's Smart Growth and Neighborhood Conservation Act of 1997. Zoned to be an industrial center, the peninsula experienced a proliferation of distribution centers and warehouses. This led to excessive truck traffic on the rural road network causing serious safety issues for local residents. Maryland DOT took the lead in forming a team with several state departments (including the Governor's Office of Smart Growth), county and community members, and entered into a six month visioning 
process to create a new land use plan for the peninsula. The new plan consisted of more mixeduse development and created opportunities to operate local transit in the area. By working together, the DOT and the county were able to create a more affordable plan that was in tune with the state's Smart Growth goals.

Revitalization of Martin Luther King Jr. Blvd, Portland. City of Portland staff has been working to integrate highways into the city by making them pedestrian-oriented while supporting the state's goal of preserving capacity. Officials from the city and state are making efforts to find funding for the city to adopt what are known as "orphan highways". These "orphan highways" run parallel to state freeways and serve local traffic though they historically belong to ODOT. Martin Luther King Jr. Boulevard, a state highway in northeast Portland, a highway revitalization project jointly undertaken by state and local agencies in 1997, serves as an exemplar. Previously a major north-south regional linkage, this 3.5-mile corridor now serves as a main street for a dense mix of urban land uses. Portland's Office of Transportation, ODOT and Metro worked with a consultant team and neighborhood groups to create a plan that balances pedestrian and neighborhood livability functions with traffic circulation.

\section{Lessons learned}

The interviews with the respondents reveal both common practices and unique approaches, but the common goal remains that of coordinating land development and transportation planning decisions to optimize limited money, time, and staff resources. This section describes lessons drawn from the experiences of the 52 respondents and the actions they recommend for improving coordination of land use and transportation planning along state highways (Table 3). A systematic assessment of the effectiveness of the recommended actions was beyond the scope of this study. Instead, this section presents a catalog of strategies, proposed by officials who have worked to improve coordination, from which officials in other agencies facing similar challenges can draw.

\section{Table 3 goes here}

\section{Actions for Cities}

Integrate Access Management Policies and Corridor Plans with Local Plans. Though most cities have comprehensive plans with a transportation element in them, the plans are not very thorough and do not show the linkages of local street networks to state highways. Respondents from nine of the eleven states thought that access management policies and corridor plans can become more effective if they are integrated into the local comprehensive planning process and plans.

Recognize Mutual Benefits to Partnership. The most common reasons that cities partner with DOTs are (1) an awareness of the mutual benefits of coordinating land use-transportation decisions; (2) recognition that good access control can increase safety and mobility in their communities; and (3) access to state funds and technical support through such partnerships. Many cities also want to stay competitive in their regions by maintaining an edge as prosperous, livable communities. 
Use Planning Staff as Educators. It is beneficial to have a planning staff, especially in smaller city agencies that can educate developers about the benefits of adopting access management early into the land development process.

Build Developer Buy-in. Though there are no state-mandated laws in Michigan, local townships were able to adopt access management ordinances successfully and this was partly possible because city officials could gradually convince local developers about the mutual benefits of access management. This instance also shows that the developers are willing to comply with the city policies if they are imposed consistently and serve the developers' long-term interests too.

Impose Stricter Access Controls. City governments do not always comprehend that developers need local business as much as the city needs to expand its tax base, and thus tend to accommodate the developer's demands for direct access to major arterials, ignoring the traffic impacts of the land development on the entire transportation system. Cities should recognize the reciprocal nature of the developer-city relationship, and impose stricter access controls and fees to make developers pay their fair share towards mitigating land development impacts on the state highway.

\section{Actions for Counties}

Use County Regulatory Power. Counties in many states (for example, Florida, Washington, Colorado, and Michigan) have almost all the regulatory powers as cities do. The benefits of the county having regulatory powers are twofold: (1) the county can regulate the land use occurring outside city limits; and (2) the county and city can work together on a wider area through intergovernmental agreements to coordinate planning decisions for growth management.

\section{Actions for State DOTs}

DOTs Can Educate Cities. In ten of the eleven states, officials mentioned that the cities look to the DOTs to initiate the coordination process, and that state and district DOT offices can play an active role in educating communities about the benefits of coordinating land use and transportation planning. Besides arranging workshops, seminars and classes to educate communities, DOTs in Oregon and Washington have developed manuals to educate developers and also district DOT staff (particularly the development review staff), about the policies and rules that they need to know while working with municipalities.

Implement Comprehensive Land Regulation along Highway Corridor. It is difficult, if not impossible, to take away permits from developers once they are given permits. To avoid such situations, it is preferable to regulate land use and transportation issues for a highway corridor in a comprehensive manner rather than practice parcel-by-parcel planning.

Encourage City Participation in Access Permit Decisions. In all states, the DOT has the final authority on access permits to the state highway, unless enabled by law to pass on the authority to cities in the district that want it. In states like Colorado and Florida, the cities and counties have the "issuing authority" to give permits within their jurisdictions, but they generally defer the decision to the DOT. The reasons that they do it are: (1) an acceptance of the DOT's expertise in traffic operational decisions; (2) unwillingness to accept liability on safety issues; (3) no incentives for cities in states where the permit review process does not generate much or any 
revenue for the city. By involving city officials in discussions regarding access-related matters, the DOT can gain a better understanding of local requirements.

Encourage and Support Small Cities. Smaller jurisdictions are unable to coordinate their planning efforts with the state because they do not have adequate staff, information or resources. But they tend to have a greater willingness to work with the DOTs than big cities because they need the funding and technical support that the DOT may provide. The state agency should try to engage these small cities in a mutually beneficial dialogue that leads to long term planning solutions.

Enforce Developer Mitigation. DOT officials from six states in this study feel that though land development does impact traffic downstream and upstream on the highway, property owners mitigate the impacts of their property only in the immediate vicinity of their property and not to the entire system. In states like Colorado and Washington, state law enables the DOTs to require impact fees from developers building along the highway.

Avoid Bureaucracy and Delays by Modifying Work Culture. City officials and project consultants in three states expressed frustration in having to deal with the DOTs, which they perceive as large bureaucracies that can be inflexible in situations requiring creative planning solutions. If a local planning/design proposal does not fit exactly within standard DOT regulations, much time may elapse before it receives the attention and approval of upper-level DOT managers. Steps should be taken to modify the work culture to be more flexible and accommodative to creative planning.

\section{The Role of MPOs and Other Regional Agencies}

MPOs are a Useful Forum for Dialogue. MPO meetings provide a useful forum for officials from different agencies to meet, build good working relationships, and discuss local and regional transportation issues.

Long-Range Plans Should Include Land use. MPOs create long-range plans that identify local arterial systems in conjunction with state highways, but these long-range plans often do not reflect land use-transportation connections.

Develop Regulations that Cities can Adopt. City and MPO officials in Florida and Wisconsin feel that the MPOs could play an active role in developing regulations that the local governments can then adopt. The City of Lakeland, Florida and the Polk County adopted the MPO's multimodal LOS standards that came out of the MPO's long-range plan into their ordinances.

Regional Agencies Beneficial. States like Oregon, Michigan and Washington have other regional agencies to oversee integrated land use-transportation planning. Having other regional agencies appears to be beneficial because: (1) the state and local agencies have more opportunities to meet, discuss issues of mutual interest and seek ways to work together; and (2) discussing issues at a regional level improves understanding of the widespread and related impacts of land development and transportation infrastructure provision. 


\section{Actions Supporting State-Local Coordination}

Establish Early DOT Involvement. Generally the DOT and the local agency interact during the state highway access permit process and the comprehensive plan review process. Towns like San Antonio, Texas and Aurora, Colorado identify the DOT as a referral agency in the development proposal review process; thus the DOT gets involved early in the land development process.

Have Willingness to Work Together. Whether the state has supporting legislation (Oregon, Delaware) or not (Texas, Michigan), the cities must have the willingness to work with the DOT for successful coordination efforts to take place.

Dialogue Leads to Solutions. Officials in nine out of the eleven states say that initiating and sustaining a dialogue with the cities is a time-consuming and resource-intensive process, but it is well worth the effort because the agencies ultimately find solutions that address all their concerns.

Introduce Access Management Guidelines in Local Plans. Respondents from six states favored the inclusion of access management guidelines in local plans that could be used to educate both district DOT officials and cities about the benefits of linking transportation and land use planning.

More Interaction Means Better Relations. Though all the states and local governments interact formally at the MPO table and in all eleven states at the project review level, successful examples of coordination reflect good sustained relationships (which grow due to constant interaction) at individual levels between the officials of these two entities. This is reflected in the examples of San Antonio, Portland and Snohomish County.

Avoid "Divide and Conquer" Conflicts. Sometimes a simple action like picking up the phone and talking to each other can help the officials from DOT and the local jurisdictions in overcoming the "divide and conquer" tactics that some developers may adopt to get their work done.

Recognize DOT's Authority. City officials from seven states noted that that it is important for the DOT to feel that the city is not taking authority away from them. Interestingly the same sentiment was expressed by DOT officials in all eleven states, who said that they respected the city's land use decisions and tried to work around them.

Share Knowledge. Coordination reduces conflicts between the DOT and the city. By working closely together, the agencies are able to appreciate the other agency's abilities and limitations. The agencies are also able to benefit from each other's knowledge and expertise. By meeting and talking regularly, officials from the DOT, city and developers may find opportunities to consolidate their different projects for the same area into a single big project and thus avoid duplication of work.

Promote Inter-agency Coordination. Inter-agency coordination helps the agencies in providing more thorough and accurate information to the development proposal applicant and thus coordination can save the developer time and money during the permit application and 
construction process. Ideally, the developer should be given the opportunity to communicate with the DOT and city in joint meetings.

Make Timely Decisions. By coordinating and conveying these decisions to the developers in a timely manner, the cities could get better land developments.

Limit Access. Both agencies have limited funds and can benefit from working together on limiting access so that existing roadways can be utilized more efficiently before adding more capacity.

\section{Legislation}

Encourage Dialogue between State-Local Agencies. In general, legislation is neither popular nor highly effective in empowering state agencies to moderate land development along highways. Cities in Oregon and Washington have benefited from state growth management laws, which enable them to collect fees from developers. Respondents from the nine states with legislation addressing land use and transportation issues (See Table 2) agreed that legislation provided them with additional forums to interact and discuss issues. But they did not see additional regulations to necessarily be the most effective method to promote a better dialogue between the state-local agencies. Respondents from all eleven states were unanimous in identifying a willingness to communicate and coordinate as the best way to advance productive dialogue between the state and local agencies.

Adopt Holistic Approach to Community Planning. Tying in access management and corridor preservation with other state policies (such as growth management and environmental protection) helps local and state agencies holistically approach community planning in harmony with the state goals.

\section{Conclusion}

This study shows that there are no set formulae to achieve coordination between state and local agencies even within the same state or region. The techniques used in different regions to coordinate land use and transportation along state highways often reflect the unique characteristics of each situation and can vary considerably. Yet common lessons emerge from the experiences described by the participants in this study as well. As the interviews show, whether or not a state has supporting legislation, a local jurisdiction's "buy-in” or willingness to partner with the DOT remains a critical factor in shaping the success of coordination efforts for optimal land use management along state highways. In addition, an awareness of the linkages between land use, transportation systems, and other "quality of life” issues among state and local agencies, local leaders, and the public at large plays a vital role in motivating DOT and city officials to aim for innovative coordination techniques. 


\section{References}

Secretary of Transportation. (1994). “Appendix-B: Report of the Secretary of Transportation to the United States Congress on Preservation of Transportation Corridors"

$<$ http://www.fhwa.dot.gov/environment/guidebook/vol2/doc5a.pdf $>$ (Apr 5, 2003)

Bass, Patricia.L., Crawford, Jason.A., Hall, Kevin M., Farnsworth, Stephen F. and Pugh, David L. (1996). Corridor Preservation A Review of Strategies for Texas, Texas Transportation Institute, The Texas A\&M University System, College Station, Texas.

Carlson, Daniel, and King, Stephen. (1998). Linking Transportation and Land use by Fostering Inter-jurisdictional Cooperation Enabling Legislation in Eight States, Institute of Public Policy and Management, University of Washington, Seattle, Washington.

Lazarz, Joanne. (1994). Corridor Preservation and Access Management Guidance, Division of Planning and Budget, Wisconsin Department of Transportation, Madison, Wisconsin.

Marshall, Margaret.A., and Williams, Kristine M. (1998). Intergovernmental Coordination in Access Management, Center for Urban Transportation Research, University of South Florida, Tampa, Florida.

National Cooperative Highway Research Program (NCHRP). (2000). Synthesis 289 Corridor Management A Synthesis of Highway Practice, Transportation Research Board, National Academy Press, Washington D.C.

National Cooperative Highway Research Program (NCHRP). (2001). Synthesis 297 Building Effective Relationships Between Central Cities and Regional, State and Federal Agencies A Synthesis of Highway Practice, Transportation Research Board. National Academy Press, Washington D.C.

Vanka, S., S. Handy, K. Kockelman. (2003). State-Local Coordination for Managing Land Use along State Highways. Center for Transportation Research, University of Texas at Austin. Product paper for TxDOT Implementation Project 5-1873.

Victoria Transport Policy Institute. (2003). Access Management.

$<$ http://www.vtpi.org/tdm/tdm1.htm> (Jul 17, 2003). 
Table 1. List of Interviewees

\begin{tabular}{|c|c|c|c|}
\hline State & Name & Title & Agency* \\
\hline \multirow[t]{7}{*}{ Colorado } & Chris Fasching & Principal & $\begin{array}{l}\text { Felsburg, Holt \& Ullevig, Greenwood } \\
\text { Village }\end{array}$ \\
\hline & Chuck Binford & Region Access Manager & Colorado DOT, Aurora \\
\hline & Ron Coontz & Transportation Engineer & Douglas County \\
\hline & Mac Callison & Principal Planner, Transportation & City of Aurora \\
\hline & Tess Jones & Region Access Manager & Colorado DOT, Greeley \\
\hline & Rita Gerou & Planning Director & City of Castle Rock \\
\hline & Phil Demosthenes & Access Program Coordinator & Colorado DOT, Denver \\
\hline \multirow[t]{3}{*}{ Delaware } & Bob Kleinburd & Environmental Program Manager & Federal Highway Administration, Dover \\
\hline & Monroe Hite & Project Engineer & Delaware DOT, Dover \\
\hline & Joe Cantaloupo & Assistant Director of Planning & Delaware DOT, Dover \\
\hline \multirow[t]{6}{*}{ Florida } & Gary Sokolow & Systems Planning Office & Florida DOT, Tallahassee \\
\hline & Joe Santos & Systems Planning Office & Florida DOT, Tallahassee \\
\hline & John Czerepak & Growth Management Coordinator & Florida DOT, Bartow \\
\hline & Andy Getch & Senior Engineer & Florida DOT, Lee County \\
\hline & Chuck Barmby & City Transportation Manager & City of Lakeland \\
\hline & Kristine Williams & $\begin{array}{l}\text { Program Director, Planning \& Corridor } \\
\text { Management }\end{array}$ & University of South Florida \\
\hline \multirow[t]{3}{*}{ Kansas } & Chris Huffman & Corridor Management Coordinator & Kansas DOT, Wichita \\
\hline & Kent Laas & $\begin{array}{l}\text { Community Development Services } \\
\text { Coordinator }\end{array}$ & City of Hays \\
\hline & Les Mangus & Planning and Zoning Administrator & City of Andover \\
\hline \multirow[t]{2}{*}{ Maryland } & Crystal Saunders & Senior Transportation Planner & Parsons Brinckerhoff Inc., Baltimore \\
\hline & Don Halligan & $\begin{array}{l}\text { Manager, Transportation \& Land Use } \\
\text { Planning }\end{array}$ & Maryland DOT, Hanover \\
\hline \multirow[t]{3}{*}{ Michigan } & Dave Geiger & Transportation Planner & Michigan DOT, Saginaw \\
\hline & Mark Graham & Planning Director & Delta Township \\
\hline & Becky Harvey & Community Consultant & Kalamazoo County \\
\hline \multirow[t]{4}{*}{ New Jersey } & Arthur Eisdorfer & Manager, Bureau of Civil Engineering & New Jersey DOT, Trenton \\
\hline & Donna Lewis & Planning Director & Mercer County \\
\hline & Paul Pogorselzki & Principal & VanCleef Consultants, New Jersey \\
\hline & Lee Solow & Planning Director & Regional Planning Board, Princeton \\
\hline \multirow[t]{6}{*}{ Oregon } & David Boyd & Region Access Management Engineer & Oregon DOT, Bend \\
\hline & Del Huntington & Access Management Program Manager & Oregon DOT, Salem \\
\hline & Jim Bryant & Planner & Oregon DOT, Bend \\
\hline & Kate Poole & Senior Transportation Planner & Oregon DOT, Salem \\
\hline & Jeanne Harrison & Senior Transportation Planner & Office of Transportation, City of Portland \\
\hline & Sonya Kazen & Associate Planner & Oregon DOT, Portland \\
\hline \multirow[t]{4}{*}{ Washington } & Robert E. Jones & Transportation Planning Manager & Washington DOT, Olympic Region \\
\hline & Dale Severson & P.E., Development Services Engineer & Washington DOT, Olympic Region \\
\hline & Todd Carlson & Regional Planning Branch Manager & Washington DOT, Olympia \\
\hline & Ramin Pazooki & Planning Developer Services Manager & Washington DOT, King County Area \\
\hline Wisconsin & Douglas Dalton & Chief, Urban Systems Planning & Wisconsin DOT, Madison \\
\hline
\end{tabular}




$\begin{array}{llll}\text { Texas } & \text { Bob McDonald } & \text { Transportation Planning Manager } & \text { Madison MPO } \\ \text { Ed Collins } & \text { Advanced Transportation Planning Director } & \text { Texas DOT, Austin District } \\ \text { Darcie Shipaul } & \text { Plan Reviewer / Transportation Specialist } & \text { Permit Office, Texas DOT, Austin District } \\ \text { Ricardo Dominguez } & \text { Transportation Planner } & \text { City of Austin } \\ \text { Rosemary Staley } & \text { Manager } & \text { MPO, El Paso } \\ \text { Judy Ramsey } & \text { Advanced Tranner } & \text { City of El Paso } \\ \text { Jack Lord } & \text { Administrator } & \text { Texas DOT, El Paso } \\ \text { Clay Smith } & \text { Planner } & \text { Texas DOT, El Paso } \\ \text { Richard De la cruz } & \text { Project Engineer } & \text { P.E. Sr. Engineer } & \text { Texas DOT, San Antonio } \\ \text { Todd Sang } & \text { Sr. Engineering Technician } & \text { Traffic Impact Studies, City of San Antonio } \\ \text { Peer Chacko } & \text { Chief Planner } & \text { Traffic Impact Studies, City of San Antonio } \\ \text { Frances Willison } & \text { Director, District ROW } & \text { City of Dallas } \\ \text { Robin Sterry } & \text { Assistant Executive Director } & \text { Texas DOT, Houston District } \\ \text { * DOT = Department of Transportation; MPO = Metropolitan Planning Organization }\end{array}$




\section{Table 2. State laws enabling state-local coordination}

\begin{tabular}{|c|c|c|c|}
\hline State & Regulation & Year & Scope of Regulation \\
\hline Colorado & State Highway Access Code & 1981 & $\begin{array}{l}\text { All accesses constructed on a state highway require a state-approved } \\
\text { access permit (updated twice). }\end{array}$ \\
\hline Delaware & Corridor Preservation Law & 1996 & $\begin{array}{l}\text { Gives the Delaware DOT authority to regulate growth and land } \\
\text { development along designated corridors }\end{array}$ \\
\hline \multirow[t]{2}{*}{ Florida } & Growth Management Act & 1985 & Requires coordination on access management and concurrency \\
\hline & $\begin{array}{l}\text { State Highway System Access } \\
\text { Management Act }\end{array}$ & 1988 & $\begin{array}{l}\text { Gives DOT authority to regulate driveway locations on state } \\
\text { highways }\end{array}$ \\
\hline Kansas & Corridor Management Policy & 1999 & $\begin{array}{l}\text { Enables DOT to assist cities in identifying "protected" corridors with } \\
\text { funding for highway improvements and planned land development }\end{array}$ \\
\hline Maryland & $\begin{array}{l}\text { Smart Growth and } \\
\text { Neighborhood Conservation } \\
\text { Act }\end{array}$ & 1997 & $\begin{array}{l}\text { Enables the state to take a broader perspective of linkages between } \\
\text { land use and transportation systems }\end{array}$ \\
\hline \multirow[t]{2}{*}{ New Jersey } & $\begin{array}{l}\text { State Highway Access } \\
\text { Management Act }\end{array}$ & 1989 & $\begin{array}{l}\text { Requires the DOT to adopt a comprehensive access code with a } \\
\text { classification system and administrative procedures for approving } \\
\text { access permits }\end{array}$ \\
\hline & $\begin{array}{l}\text { Transportation Development } \\
\text { District (TDD) Act }\end{array}$ & 1989 & $\begin{array}{l}\text { Enables creation of districts where intense growth is expected and } \\
\text { enables assessment and charging development fees on land } \\
\text { developments within the district boundaries for impacts on traffic }\end{array}$ \\
\hline \multirow[t]{2}{*}{ Oregon } & $\begin{array}{l}\text { Transportation Planning Rule } \\
\text { (TPR) }\end{array}$ & 1991 & $\begin{array}{l}\text { Sets requirements for coordination between local and state agencies } \\
\text { for preparation, implementation and amendment of long-range } \\
\text { transportation system plans (TSP) to be developed by all } \\
\text { jurisdictions with populations over 2,500. The TPR requires TSPs to } \\
\text { be consistent with statewide transportation goals }\end{array}$ \\
\hline & 1999 Oregon Highway Plan & 1999 & $\begin{array}{l}\text { Includes policies related to cooperative partnerships and public } \\
\text { involvement }\end{array}$ \\
\hline Washington & $\begin{array}{l}\text { Growth Management Act } \\
\text { (GMA) }\end{array}$ & 1990 & Requires city plans to be consistent with statewide goals \\
\hline Wisconsin & $\begin{array}{l}\text { Comprehensive Planning and } \\
\text { "Smart Growth" legislation }\end{array}$ & 1999 & $\begin{array}{l}\text { Requires all municipalities (including rural areas) to have } \\
\text { comprehensive plans consistent with state requirements by January } \\
\text { 1, } 2010\end{array}$ \\
\hline
\end{tabular}




\section{Table 3. Lessons Learned and Recommended Actions}

Actions for Cities

Actions for Counties

Actions for State DOTs

The Role of MPOs and Other Regional Agencies

Actions Supporting State-Local

Coordination

Legislation
- $\quad$ Integrate Corridor Plans with Local Plans

- $\quad$ Recognize Mutual Benefits to Partnership

- $\quad$ Use Planning Staff as Educators

- Build Developer Buy-in

- Impose Stricter Access Controls

- Use County Regulatory Power

- $\quad$ DOTs Can Educate Cities

- Implement Comprehensive Land Regulation

- Encourage City Participation in Access Permit Decisions

- $\quad$ Encourage and Support Small Cities

- Enforce Developer Mitigation

- Avoid Bureaucracy and Delays by Modifying Work Culture

- $\quad$ MPOs are a Useful Forum for Dialogue

- $\quad$ Long-Range Plans Should Include Land use

- Develop Regulations that Cities can Adopt

- Regional Agencies Beneficial

- $\quad$ Establish Early DOT Involvement

- Have Willingness to Work Together

- Dialogue Leads to Solutions

- Introduce Access Management Guidelines in Local Plans

- $\quad$ More Interaction Means Better Relations

- Avoid "Divide and Conquer" Conflicts

- Recognize DOT’s Authority

- $\quad$ Share Knowledge

- Promote Inter-agency Coordination

- Make Timely Decisions

- $\quad$ Limit Access

- Encourage Dialogue between State-Local Agencies

- Adopt Holistic Approach to Community Planning 